\title{
Democracy and Socio-Economic Crises in Africa: The Nigerian Experience
}

\author{
Olukemi Ajibike Aluko PhD \\ Department of Local Government Studies, Obafemi Awolowo University, Ile-Ife, Nigeria
}

\begin{abstract}
The democratic transition process, which almost all African States have inevitably swung into since the early 1980s, has made their vulnerability to social and economic crises more intense. The problems that are concomitants of these transitions, which have exacerbated the extant socio-economic problems, have been dramatized by the increased level of poverty, widening income gap, sustained low (negative in many cases) growth rate, etc. in the African states. Democracy in Africa has thus deepened the contradictions in the economy and between the weak and the powerful in both absolute and relative terms. This paper is directed at unraveling these conflicting realities, particularly the implications of the patterns for overall socio-economic development. A study of Nigeria's experiences at 'democratising' permits a clearer appreciation of the nature and trends of democracy in Africa. This is done within the context of the political economy frame work. This paper argues that, democratization in Africa is one which focuses mainly on economic deregulation and liberalization while at the same time denying the need for political decentralization that can give the weak and poor access to the gains of development, and that, the prebendial nature of politics in Africa makes it an exclusive business for the rich thus narrowing the possibility for empowerment of the poor people at the long run. It is our conclusion therefore, that the above contradictions can only be resolved if the right political context for economic democratization is created, because, in Africa, politics, more then anything else constraints economic development.
\end{abstract}

Keywords: Democracy, Democratization, Socio-Economic Crises, Development and Political Economy

DOI: $10.7176 / \mathrm{JESD} / 12-8-03$

Publication date: April $30^{\text {th }} 2021$

\section{INTRODUCTION}

The implosion of communism which ended the ideological Cold War between the East and West has left the world with the dominant superpower in the USA. This American hegemony has been the heart of unipolarism since the 1990s. One of these outcomes is the 'imposition' of liberal democracy on all states across the globe. But because, the nature and character of the political economy of most States in Africa, as they currently are, is basically at variance and incompatible with the principles and conditions for successful democratization, the process has created so much social and economic crises in these countries. This is particularly so for Nigeria where the current living standard of the citizenry is not in significant ways better than what they were in the pre-transition years.

This paper examines the entire gamut of the democracy project and the dichotomies and contradictions it has produced and enhanced in a third world country like Nigeria. In achieving this, we adopt the political economy approach in elucidating the nature of social and economic crisis that have accompanied the attempt at sustaining democracy in Nigeria.

The paper is subdivided into the following sub- sections. Just after this introductory section is an analysis of the concept of democracy and socio economic crisis. The next section examines the social crisis that is attendant on Nigeria's attempt at democratic sustenance. Conclusions are drawn in the final section.

\section{CONCEPTUALISING DEMOCRACY}

According to Appadorai (1974:37),

"democracy is that system of government under which the people exercise the governing power either directly or through representatives, periodically elected by them."

This implies that a state can lay claim to be a democratic if it provides institutions for the expression and supremacy of the popular will on basic questions of social direction and policy.

In the view Diamond etal (1988: xvi) sees democracy as

a system of government that meets three essential conditions: meaningful and extensive competition among individuals and groups (especially political parties) for all effective positions of government power, at regular intervals and excluding the use of force; a highly inclusive level of political participation in the selection of leaders and policies, at least through regular and fair election, such that no major (adult) social group is excluded; and a level of civil and political liberties - freedom to form and join organizations sufficient to ensure the integrity of political competition and participation. 
Diamond's conception of democracy is a fairly comprehensive one. It is precise enough to exclude pseudodemocracies and distinguish between semi- democracies and the fuller, more authentic variety. In addition, by focusing on the generic phenomena of competition, participation and liberty, rather than specific institutional expression, it avoids suggesting that any particular constitutional configuration is absolutely necessary to have democracy and therefore allows for new and eclectic constitutional forms to qualify" (Ake, 1992:1).

Simply put, democracy is a governmental form in which political equality, freedom and popular sovereignty of all adult citizens are presupposed.

Heater (1964: 134) identifies five basic elements of liberal democracy to be the following:

- equality,

- $\quad$ sovereignty of the people,

- respect for human life,

- the rule of law and liberty of the individual.

It also includes:

- $\quad$ elected government;

- free and fair elections in which every citizen's vote has an equal weight;

- a suffrage which embraces all citizens irrespective of distinctions of race, religion, class, sex and so on;

- freedom of conscience information and expression on all public matters broadly defined;

- the right of all adults to oppose their government and stand for office; and associational autonomy

- the right to form independent associations including social movements, interest groups and political Parties.

- Control over government decisions about policy constitutionally vested in the elected representatives.

- Elected representatives exercise their constitutional powers without facing overriding opposition from unelected officials.

- Citizens have the right to express themselves on political matters, defined broadly, without the risk of State sanctions.

- Citizens have the right to seek out alternative source of information, such as the news media, and such sources are protected by the law.

- Citizens have the right to form independent associations and organisations, including independent political parties and interest groups.

- Government is autonomous and able to act independently from outside constraint (such as those from transnational organisations, Terrorists, alliances, blocs, etc).

\section{SOCIO - ECONOMIC CRISIS.}

On a general note, it is a well known fact that 1.2 billion people one in every five of the world population live less than US \$2 per day and without the basic essentials of life - shelter, food, water, sanitation, adequate healthcare etc. Most part of this number comes from the developing countries. Unfortunately, the above situation exists at a time some parts of the world are boasting of unimaginable prosperity, incredible advances in technology, capital and material wealth. Indeed as UK Secretary of State for international development put it - "We are living at a time of profound historical change. Great wealth and great squalor exist side by side".

It is difficult resolving these contradictions that have produced two worlds, each far apart from the other. In one, represented by industrialized countries, that has since been democratized. In the other, represented by developing countries, greater vulnerability and social dislocation to the overwhelming number of the world population exist. Extreme poverty overshadows the greater part of the population of these States. Particularly people in Sub-Saharan African have become poorer today than they were 25 years ago. Growing inequality within and among States has become more pronounced today than ever, resulting in spread of conflicts and wars, contagious diseases, adult literacy and lack of infrastructural facilities, child abuse/trafficking, social exclusions among others.

\section{THE NIGERIAN EXPERIENCE}

Nigeria is a multi- ethnic and religious society. It is a plural society in every sense of the word. This plurality is a very crucial factor in the outcome of all political and economic activities and it represents a rich diversity.

The survival of the people within the Nigerian region prior to colonialism was ensured through a variety of production processes that assured the normal satisfaction of the needs of the people. These were economic processes that were internal - articulated and therefore self - propelling in that production was essentially related to the internal consumption of the different groups (Oyomvbere, 1984:138).

Colonialism brought about the monetization of the Nigerian economy and the creation of social relations of exchange. The Nigerian economy ( since then) has remain mercantilist, with buying and selling of produce/products rather than manufacturing or reproduction of productive capital being dominant (Olaitan, 1995:124-137). Theresa 
Tuner calls it a 'commercial capitalist economy. Thus the Nigerian political economy has been dominated by entrepreneurial classes nurtured on commerce ((Dike 1990: 86)

The general pattern of democracy and development in Nigeria between independence and 2010 conform with the general pattern of democracy in developing countries; being marked by constant shifts in focus and orientation.

During the periods of 1993 to 1999, Nigeria was under severe pressure both within and from the outside for not transiting politically. By 1999 when the civilian government of Obasanjo came into power, the contradictions that underlay the liberalization projects of the military regimes that repression had helped to suppress blew open. First were political crises in different parts of the country fuelled by ethnic agitations, (Ife - Modakeke, Ijaw Ilaje, Itsekiri - Urobo, Jukun - Tiv, etc), religious intolerance (Kano, Kaduna, Jos etc) and several ethnic militias emerged to 'promote' their ethnic interests (O'dua Peoples Congress, Arewa Congress, Egbesu Boys, Bakassi Boys, Oogoni Youths etc). A 'full - fledge war, was on between the Federal government troops and Youth militias in Warri, Delta state of Nigeria, over the control of oil money. They had also been incessant labor unrest in relation to workers welfare and as a protest against government's withdrawal of subsidies on essential services like education, wealth and commodities like gasoline and diesel. The story is still the same inspite of various administrations since Obasanjo left office

Available evidence indicates that poverty went up in Nigeria between 1986 and 2010. According to the economic report released in July 2014 by the World Bank; poverty in Nigeria still remains significant at $33.1 \%$ and Nigeria is Africa's biggest economy. Generally, income inequality is notoriously high in Africa, Nigeria inclusive. Inflation has continued to assault real wages and the spending capacity of low income earners has considerably withered down. Generally, in Nigeria, the poor suffered a long - term reversal in their overall capabilities in the 1980s. So, whereas, a pattern of growth has been established in the Nigerian economy since this time, the overwhelming majority of the population is worsening off. Whatever the impact democracy had for a small minority in Nigeria did not affect the great majority of the population. For instance, rising unemployment has great impact on the incident and severity of poverty that amounts to the majority in Nigeria.

Though, government successfully auctioned the GSM telecommunications licenses early 2001 and this has increased investments in this sector and boosted economic activities in Nigeria, yet great majority of Nigerians are excluded from the use by reason of network issues and high tariff of internet.

Worst of all, liberal democracy has made politics a very lucrative business in Nigeria. But rather than pursuing the public good or collective interest of the people, leaders and politicians in Nigeria are more interested and entangled in the struggle for and retention of power. The use of power for development has not been part of their visions or mission. This has contributed to the immeseration of the masses in the country.

\section{References}

Ake, Claude; (1984) "The Political Economy Approach: Historical and Explanatory Notes on A Marxian Legacy in Africa" in Ihombuere, J.O; (ed) The Political Economy of Crisis and Under-development in Africa: Selected Works of Ake. JAD Publishers, Lagos.

Appadoral A (1968), The Substance of Politics; London, Oxford Press.

Diamond L (19888), Democracy in Developing Countries: Africa vol.2; Boulder Co. Lynne Rienner Publishers.. Dike, Enwere;(1990) "The Political Economy of the Buhari Regime" Nigerian Journal of International Affairs" Vol 16, No 2 Lagos.

Mimiko, N.O;(ed) Crisis and Contradictions in Nigeria's Democratization Programme1986-1993.

Olaitan, Are Wale; (1995) "The State and Economy in Nigeria: A Conceptualisation" in Adejumobi, Said and Momoh, Abubarkar (eds) The Political Economy of Nigeria Under Military Rule 1984-1993 SAPES Books, Harare.

Oyombere, Sam; (1984) “The Nigeria State and Conceptual Variables” Studies in Politics and Society, No2

Turner, Theresa; (1978) "Commercial Capitalism and the 1975 Coup" in Keith, Panterbrick (ed) Soldiers and Oil: The Political Transformation of Nigeria. Frank Cass and Coy Limited, London. 